
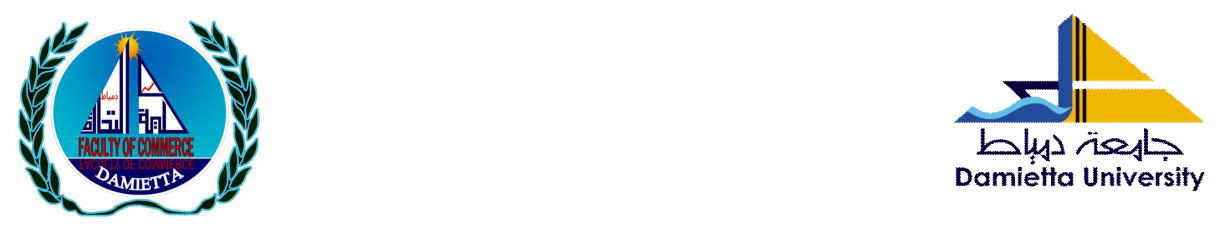

\title{
A Non-Inflationary Potential Output in Question
}

\author{
Prepared by \\ Dr. Noha Ahmed Ibrahim El-Demery \\ Lecturer of Economics at the European Universities of Egypt \\ ndemery@gmail.com
}

Scientific Journal for Financial and Commercial Studies and Researches (SIFCSR)

Faculty of Commerce - Damietta University

Vol.3, No.1, Part 1., January 2022

APA Citation:

El-Demery. N.A.I. (2022). A Non-Inflationary Potential Output in Question, Scientific Journal for Financial and Commercial Studies and Research, Faculty of Commerce, Damietta University, 3(1)1, pp. 485-495.

Website: https://cfdi.journals.ekb.eg/ 
Scientific Journal for Financial and Commercial Studies and Researches

(SJFCSR) Faculty of Commerce - Damietta University

\title{
A Non-Inflationary Potential Output in Question
}

\author{
Dr. Noha Ahmed Ibrahim El-Demery
}

\begin{abstract}
The output gap measurement helps assess a country's growth performance, fiscal space and to forecast inflationary pressures. It is measured based on the 'potential output'. The latter captures the notion that there is an equilibrium level of production and policymakers try to reach an economic environment consistent with the operation of the economy at this equilibrium. This article put the non-inflationary potential output approach in question. This is because, a noninflationary long term equilibrium would require in the short run a noninflationary economic environment which entails, according to Phillips curve, a stable unemployment rate implying then that some people who can and are willing to work will not find jobs. The alternative methodology we proposed, to measure the potential output, and therefore the output gap, relied on the hypothesis that labor is the production factor that produces and uses capital as well as develops technology. Thus, the economy will reach its potential output when the unemployment rate is zero. This methodology enables to align macroeconomic policies objectives in order to support employment. The unemployed willingness to work won't be offended by macroeconomic policies that put a noninflationary equilibrium as an ultimate objective. Besides, this methodology suggests that; policies aiming to increase the labor force as well as policies aiming to increase the real productivity by worker can expand the production capacity of the economy i.e., its potential output. It also suggests that; policies aiming to reduce the unemployment rate can help the economy reach full employment i.e., its full capacity.
\end{abstract}

JEL Classification : E01 ; E63 ; F43 ; J2.

Keywords: National Income Accounting; Fiscal Policy; Inflation Stabilization; Open Economy Growth; Employment. 


\section{Dr. Noha Ahmed Ibrahim El-Demery}

\section{Introduction}

The concept of potential output is among the fundamental ideas of macroeconomics. It captures the notion that there is a long term equilibrium or optimal level of production. Therefore, policymakers endeavor to reach an economic environment consistent with the operation of the economy at this optimal level (Grech and Aaron, 2014). On the fiscal side, the concepts of potential output and output gap are part of the international monetary fund framework to define a country's fiscal space $^{1}$. They are among the concepts at the core of the fiscal surveillance framework of the European Union (EU) as defined in the Stability and Growth Pact (SGP) 1 and in the Treaty on Stability, Coordination and Governance in the Economic and Monetary Union (TSGC - also known as Fiscal Compact (Navarini and Zoppè, February 2020). Moreover, the output gap is used by central banks in preparing inflation forecasts and in assessing economic performance (Central Bank of Iceland, 2005).

There are two main definitions of potential output in literature. The first; potential output is "the maximum amount of goods and services an economy can turn out when it is most efficient - that is, at full capacity. Often, potential output is referred to as the production capacity of the economy" (Jahan and Mahmud ${ }^{2013)}$. The second is "potential output is a key economic concept as its evolution determines how fast an economy can grow in a sustainable way. It is typically thought of as the highest level of economic activity that can be sustained by means of the available technology and factors of production, in particular labor and capital, without creating inflationary pressure" (Andersson et al., 2018). Therefore, the second interpretation links potential output to a noninflationary status.

As for the Output gap definition; as Jahan and Mahmud (2013) have explained; an output gap suggests that an economy is running at an inefficient rate-either overworking or underworking its resources. A positive output gap occurs when actual output is more than potential output. A negative output gap occurs when actual output is less than potential output; whereas full employment corresponds to an output gap

${ }^{1}$ International Monetary Fund, June 2018. 
Scientific Journal for Financial and Commercial Studies and Researches (SJFCSR) Faculty of Commerce - Damietta University

of zero. In practice, $\mathrm{t}^{\text {he output gap1=((Actual Real GDP-Potential Real GDP)/Potential Real }}$ GDP)*100; where the GDP is the Gross Domestic Product.

The status of the output gap impacts macroeconomic policy decisions. As Jahan and Mahmud (2013) have emphasized; all other things being equal, if the output gap is positive over time, prices will begin to rise in response to demand pressures in key markets. Whereas if actual output falls below potential output over time, prices will begin to fall to reflect weak demand. The monetary policy may respond, for instance; in an inflation targeting regime, when the output gap is negative, the central bank may lower the policy rate to boost demand and prevent inflation from falling below the central bank's inflation rate target. Governments can also use fiscal policy to close the output gap. For example, an expansionary fiscal policy can be used to close a negative output gap.

The unemployment gap is a concept closely related to the output gap (Jahan and Mahmud, 2013). The unemployment gap is the difference between the unemployment rate and the nonaccelerating inflation rate of unemployment (NAIRU) (Cusbert, 2017) sometimes referred to as the natural unemployment rate. Jahan and Mahmud (2013) have elaborated that; the NAIRU is the unemployment rate consistent with a constant rate of inflation. Theoretically, if policymakers get the actual unemployment rate to equal the NAIRU, the economy will produce at its maximum level of output without straining resources - in other words; there will be no output gap and no inflationary pressures. Grech and Aaron (2014) have explained that; in this context; any deviation of the unemployment rate from the exogenously determined NAIRU, is used to determine the output gap.

On the empirical level, estimates of the potential output and of the output gap (reviewed in Grech and Aaron, 2014) have been criticized. This is as estimates are based on one or more statistical relationship and therefore contain an element of randomness (Jahan and Mahmud, 2013). The question that follows; which potential output definition and

${ }^{1}$ Central Bank of Iceland, 2005. 


\section{Dr. Noha Ahmed Ibrahim El-Demery}

measurement to adopt and accordingly measure the output gap? And what are the policy implications?

\section{Methodology}

The article aligns with the definition of potential output according to which potential output is "the maximum amount of goods and services an economy can turn out when it is most efficient-that is, at full capacity. Often, potential output is referred to as the production capacity of the economy" (Jahan and Mahmud, 2013).

Our methodology to measure the potential output and accordingly measure the output gap relies on the hypothesis that labor is the production factor that produces and uses capital as well as develops technology. We calculate then a proxy of potential real GDP by calculating the real GDP in case of zero unemployment. Our methodology is backed by Romer (1986) conclusion that growth can continue without technical progress if the notion of technical capital is enlarged to encompass human capital (knowledge, quality) and by Bodin, a 16th century philosopher and economist, well known expression 'Man(kind) is the only true source of wealth'.

To give an application of the methodology we propose, we refer to the Egyptian economy data, whereas this methodology can be applied for any economy at any point of time:

The Egyptian real GDP in July-March 2019/20 was LE 3004800 million $^{1}$ and the number of employed was 26.772 million $^{2}$.

The real productivity by worker $=($ real GDP/number of employed $)$ $=(3004800 / 26.772)=$ LE 112236.7 .

The number of unemployed was 2.236 million in March 2020 registering an unemployment rate of $7.7 \%$. Multiplying the number of unemployed by real productivity by worker, we can then have, all other things being equal, a proxy of potential additional real GDP in case of full employment $(2.236 * 112236.7)=$ LE 250961.2.

\footnotetext{
${ }^{1}$ Central Bank of Egypt, September 2020.

${ }^{2}$ Central Agency for Public Mobilization and Statistics, July 2020.
} 
Scientific Journal for Financial and Commercial Studies and Researches

(SJFCSR) Faculty of Commerce - Damietta University

To have, all other things being equal, a proxy of potential real GDP, we sum up real GDP and potential additional real GDP $(3004800+250961.2)=$ LE 3255761.2 million.

The output gap is defined as the difference between actual and potential GDP as a per cent of potential GDP $=\left(\left(3004800-3255761.2^{)}\right.\right.$ $3255761.2^{* * 100}$. The output gap was therefore $-7.7 \%$ i.e. equivalent, in absolute terms, to the unemployment rate in March 2020; this is as man is the production factor that produces and uses capital as well as develops technology.

\section{Discussion}

We disprove potential output definition that defines potential output as a non-inflationary equilibrium. This is because, while inflation and unemployment are independent in the long run; there is a trade-off between these two variables in the short-term as has been shown by Phillips curve that has illustrated the inverse relationship between unemployment and inflation, with inflation on the $\mathrm{Y}$-axis and unemployment on the $\mathrm{X}$-axis of a downward slopping curve (Phillips, 1958).

To explain this trade-off between unemployment and inflation; the monetary and fiscal policies can be used in the short run to simulate aggregate demand, this stimulation reduces unemployment and increases inflation. Likewise, they can be used to restrict aggregate demand, which increases unemployment and reduces inflation (Mankiw, 2010). Therefore, a non-inflationary level of production implies in the short run, all other things being equal, that the unemployment rate doesn't change.

But, keeping a constant unemployment rate has a cost. Since the unemployment rate is calculated based on the labor force (those who can and are willing to work), if the policymakers work to reach a noninflationary equilibrium with a constant unemployment rate, then they will be working to keep some people who can and are willing to work unemployed, which is an undesirable situation on both the social and the economic levels. Accordingly, we didn't use the deviation of the unemployment rate from the exogenously determined NAIRU to determine the output gap. This is because, similarly, if the monetary and/or fiscal policy act in order to keep the unemployment rate at the 


\section{Dr. Noha Ahmed Ibrahim El-Demery}

NAIRU level, while they can act to lessen it below the NAIRU, this means again that they will be acting to keep part of those who can and are willing to work unemployed which is against human welfare. Besides, the NAIRU measurements or the natural unemployment rate have proved to be imprecise (Mankiw, 2010 and Staiger et al., 1997).

\section{Conclusion and Policy Implications}

The framework of analysis of potential output proposed in this article, which relied on the hypothesis that labor is the main production factor, suggests that; all policies aiming to increase the labor force i.e. increase the number of those who can and are willing to work as well as all policies aiming to increase the real productivity by worker will expand the production capacity of the economy i.e. its potential output. This includes for instance policies to reduce the gap between the outcome of the education system and the requirements of the job market. The framework of analysis of potential output proposed in this article also suggests that; policies aiming to reduce the unemployment rate can help the economy reach full employment i.e., its full capacity. This includes for example policies to increase domestic investments as well as policies to attract foreign direct investments in order to generate new jobs.

Concerning the negative impact, in case of full employment, of higher inflationary pressures; it is worth reminding that it remains within the short term and that countries are expected to develop safety nets and to take measures to protect the vulnerable to higher inflation levels. Besides, inflation is influenced by many variables, local ones as well as international ones. Therefore, although higher employment can increase inflationary pressures in the short run this effect may be counterbalanced for instance by lower international commodities prices at the time of high employment. Moreover, we expect that; in reality, full employment can hardly be achieved. This is because the labour market is evolving all the time witnessing seasonal unemployment and/or structural unemployment (when the real wage is higher than its equilibrium level and when labour supply is higher than its demand) and/or cyclical unemployment (Mankiw, 2010) and has a natural unemployment rate that can't be precisely determined. 
Scientific Journal for Financial and Commercial Studies and Researches (SJFCSR) Faculty of Commerce - Damietta University

Further research is needed to learn more about the factors that can expand the economy production capacity and about the possible constraints to reach full employment.

\section{References}

Andersson, Malin; Szörfi, Bela; Tóth, Máté and Zorell, Nico, 2018, 'Potential Output in the Post-Crisis Period', ECB Economic Bulletin, Issue 7/2018.

Bodin, Jean, 2017, 'Les Six Livres de la République', Myriel.

Central Agency for Public Mobilization and Statistics, July 2020, Quarterly Labour Force Survey (Analytical report).

Central Bank of Egypt, September 2020, Monthly Statistical Bulletin (283).

Central Bank of Iceland, 2005, 'Appendix 2: Calculating the Output Gap', Economic and Monetary Developments and Prospects, Monetary Bulletin, 2005 (1).

Cusbert, Tom, 2017, 'Estimating the NAIRU and the Unemployment Gap', Reserve Bank of Australia, Bulletin June Quarter 2017.

Grech, Aaron G., 2014, 'Investigating Potential Output Using the Hodrick-Prescott Filter: An Application for Malta', Central Bank of Malta, WP/02/2014.

International Monetary Fund, June 2018, 'Got Fiscal Space?', https://www.imf.org/external/mmedia/view.aspx?vid=58020235660 $\underline{01}$

Jahan, Sarwat and Mahmud, Ahmed Saber, September 2013, 'What Is the Output Gap?', Finance \& Development, Vol. 50, No. 3.

Mankiw, Gregory N., 2010, 'Macroeconomics', Worth Publishers, New York.

Navarini, L. and Zoppè, A., February 2020, 'Potential output estimates and their role in the EU fiscal policy surveillance', Economic Governance Support Unit (EGOV), Directorate-General for Internal Policies PE 574.407, European Parliament. 


\section{Dr. Noha Ahmed Ibrahim El-Demery}

Phillips, A.W., November 1958, 'The Relationship between Unemployment and the Rate of Change of Money Wages in the United Kingdom, 1861-1957', Economica 25, 283-299.

Romer, Paul M., 1986, 'Increasing Returns and Long Run Growth', Journal of Political Economy, 94, 1002-37.

Staiger, Douglas; Stock, James H. and Watson, Mark W, 'How Precise are Estimates of the Natural Rate of Unemployment?', in C. Romer and D. Romer, Eds., Reducing Inflation: Motivation and Strategy, Chicago: University of Chicago Press, 1997. 
Scientific Journal for Financial and Commercial Studies and Researches

(SJFCSR) Faculty of Commerce - Damietta University

الناتج المحتمل غير التضخمي قيد السؤال

\author{
نهى أحمد إبراهيم الدميرى \\ مدرس اقتصاد فى الجامعات الأوربية في مصر.
}

الملخص:

يساعد قياس فجوة الناتج في تقييم أداء النمو الاقتصادي، والحيز المالي، و التنبؤ بالضغوط التضخمية. يتم قياس فجوة الناتج على أساس "الناتج المحتمل". يجسد الأخير فكرة أن فئ

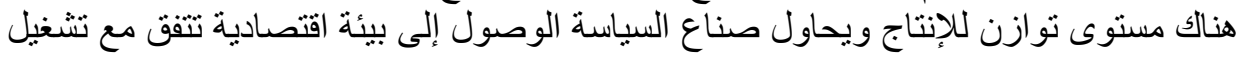

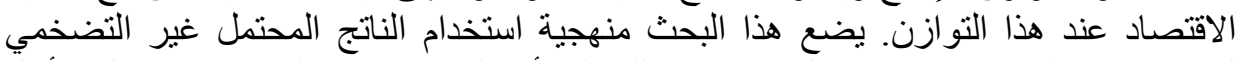

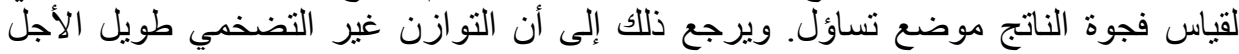

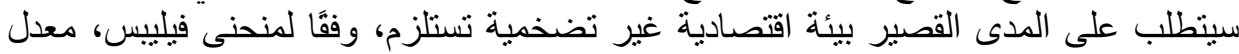

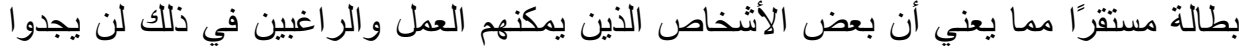
وظائف. اعتمدت المنهجية البديلة التي اقترحناها لقياس الناتج المحتمل، وبالتالي فجوة الناتج، على فرضية أن العمل هو عامل الإنتاج الذي ينتج ويستخدم رأس المال وكذللك بطور

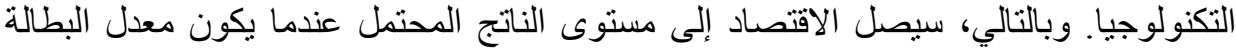
صفرَّ. تمكن هذه المنهجية من مواءمة أهداف سياسات الاقتصاد الكلي من أجل دعم التوظيف.

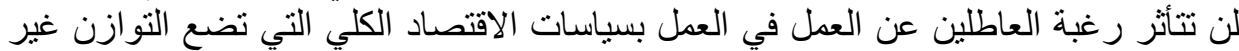

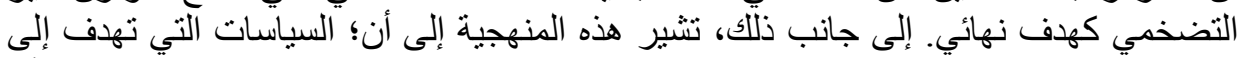

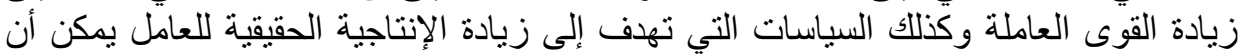

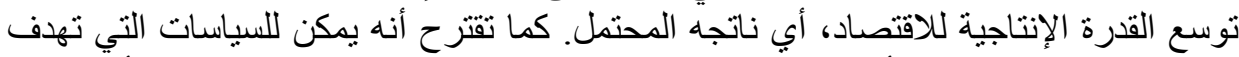

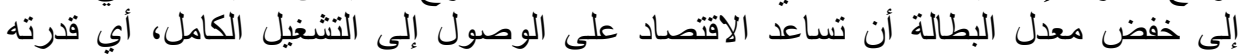

E01; E63; F43; J2. :JEL التصنيف وفقال

الكلمات الرئيسيت: حساب الدخل القومي؛ سياسة مالية؛ استقر ار التضخم نمو الاقتصاد

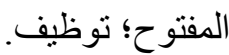

